\section{ECONOMICS}

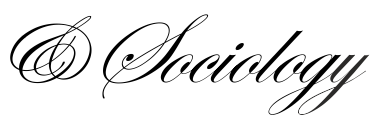

Abbasov, J., Gulaliyev, E., Ahmadov, F., \& Mammadov, I. (2021). Does the COVID19 pandemic change the relationship between government expenditures and economic growth in Azerbaijan?. Economics and Sociology, 14(3), 185-204. doi:10.14254/2071-789X.2021/14-3/10

\title{
DOES THE COVID19 PANDEMIC CHANGE THE RELATIONSHIP BETWEEN GOVERNMENT EXPENDITURES AND ECONOMIC GROWTH IN AZERBAIJAN?
}

\author{
Jeyhun Abbasov \\ Ministry of Economy of \\ Azerbaijan, State Tax Service, \\ Local Income Department \\ Baku, Azerbaijan, \\ State University of Economics, \\ Baku, Azerbaijan \\ E-mail: \\ ceybunabbasoglu@gmail.com

\section{Elchin Gulaliyev \\ Central Bank of Azerbaijan \\ Baku, Azerbaijan, \\ Azerbaijan State University of \\ Economics, \\ Baku, Azerbaijan \\ E-mail:gul.elchin@gmail.com}

\section{Fariz Ahmadov \\ Azerbaijan State University of \\ Economics, \\ Baku, Azerbaijan \\ E-mail:ahmadovfs@hotmail.com}

\section{Ilkin Mammadov}

Azerbaijan State University of

Economics,

Baku, Azerbaijan

E-mail: ilkmammadov@gmail.com

Received: January, 2021

1st Revision: June, 2021

Accepted: September, 2021

DOI: $10.14254 / 2071-$

789X.2021/14-3/10

JEL Classification: C13, E62, F43, H5
ABSTRACT. This paper investigates the impact of the Government's capital and current expenditures on economic growth in Azerbaijan. The estimation strategy of the research consists of two directions. First, all estimation approaches were used for the period of 2005Q1-2019Q4. The estimated model for this period is called Model 1. Second, the model which is called Model 2 was estimated for whole period of 2005Q12021Q1. This approach allows comparing the role of the Government expenditures on non-oil economic activity in normal times and during the COVID-19 pandemic in Azerbaijan. Estimations show that coefficients characterizing the impact of Government current expenditures and capital expenditures on non-oil economic growth are almost the same for both periods. Therefore, we can state that COVID-19 pandemic did not affect the structure of the relationship between Government expenditures and non-oil economic growth. Results show that 1 percent increase in capital and current expenditures of state budget increases the real non-oil GDP by 0.10 and 0.40 percentage points, respectively. Accordingly, both capital and current expenditures of the state budget have positive impact on the real non-oil GDP growth for the both periods. This is in contrast to findings in the literature, which argue that increasing current expenditures financed by tax hikes lead to a lagged decrease in private investment, having an overall negative impact on economic growth. We attribute this opposing finding to the Azerbaijani state budget revenue system, which is financed by transfers from the State Oil Fund (Stabilization Fund). Thus, large government investment and social projects mostly rely on non-tax sources. Therefore, we argue that positive impact of capital and current expenditures of government budget on non-oil GDP seems plausible for Azerbaijan. Another result of our estimation is that expansion of economic openness accompanied by non-oil economic growth plunge in Azerbaijan. We interpret this phenomenon with very low share of non-oil export, where openness is mostly caused by increase in import volume.
Keywords: ARDL modeling approach, cointegration analysis, long-run effect of government spending, capital and current expenditures, fiscal multiplier 


\section{Introduction}

Beginning from the mid of the previous century, especially after the Great Depression, the governments began to expand their role in the regulation of economy. Nowadays, mostly in emerging markets, fiscal policy is gaining importance in stimulation of economic growth. However, already in the 1890s, Wagner discussed the importance of the government's role for economic growth, and unlike the classical economists, he acknowledged the relevance of fiscal policy. After the 1930s, Keynes introduced his famous concept, that the government spending is a powerful tool to affect aggregate demand and regulate the economy. Not only aggregate demand could be stimulated by high government spending; consumption and investment spending could be influenced by lowering or raising taxes. Nowadays the share of government spending in the economy is increasing and discussions about the effectiveness of fiscal multipliers are ongoing (Chen, 2006, pp. 123). Moreover, it is clear from the literature on endogenous growth that fiscal policy has potential effects on economy in long-run, as well. In this context, an investigation of the impact of government spending on the economic activity in the post-crisis period seems to be appropriate.

After collapse of the biggest socialist union (1991), Azerbaijan started transformation to market economy and rebuilt its oil industry through partnership. After the 2000s, as a small open emerging economy, Azerbaijan experienced an oil boom era and periods of high economic growth. These growth rates were mostly attained due to oil sector income that allowed huge government expenditures on public projects. However, with the end of the high oil price era and decreasing oil revenues, it became impossible to keep the same rate of public expenditures. Therefore, it turned out to be essential for policymakers to estimate the contribution of government spending on real non-oil economic growth in order to justify the ratio of current and capital expenditures.

The main goal of this research is to estimate the impact of government capital (g1) and current (g2) expenditures on economic growth (y). Moreover, we used some other variables such as real capital stock (k), openness of the country (z) and labor supply (l) to increase adequacy of the model. To estimate the testing model, we have used different methods including Autoregressive Distributed Lag (ARDL) technique, Fully Modified OLS (FMOLS), Canonical Co-Integrating Regression (CCR), Dynamic OLS (DOLS) and Generalized method of moments (GMM). The main purpose of using different methods is (i) to compare results, (ii) to find the most suitable estimation approach, and (iii) to check for robustness. The rest of the paper consists of Literature review, Data collection, Methodological approach, Discussion, and Results of the research.

\section{Literature review}

The literature on the composition of fiscal expenditures goes back by Barro (1990) and Devarajan et al. (1996). Also, Chen (2006) studied the relationship between public investment, consumption, and government expenditures and its impact on economic growth in a one-sector, endogenous growth model. Following Barro (1990), the study also adds public consumption into households instantaneous utility function, while productive public services enter the private production in an external fashion. Besides that, we also can see various types of the optimal budget allocation in the papers introduced by Chen et al. (2003), Lee (1992) and so on. Chen (2006) concludes that countries which have larger share of productive public expenditures exhibit higher economic growth rates.

Most of the empirical literature on the optimal composition of fiscal expenditures go back to Devarajan et al. (1996)'s study. Devarajan et al. (1996) focused on the link between 
various components of government expenditures and economic growth in developing countries. The hypothesis that guided this study is that public expenditures exert their impact on economic growth with a lag. On the base of this statement, their dependent variable is the five-year forward moving average of per capita real GDP growth. But, construction of the dependent variable as a five-year forward moving average of per capita real GDP growth causes serial correlation in the error terms. Therefore, to correct the standard errors Devarajan et al. (1996) extended the method of correlation correction outlined by Hansen and Hodrick (1980).

The goal of our empirical analysis is assessing the link between government's capital expenditures (as well as current expenditures) and economic activity (GDP growth). We assume that both types of expenditures are productive. In Table 1, we have tried to summarize the empirical design of some famous papers in this field.

Table 1. Empirical design of early researches

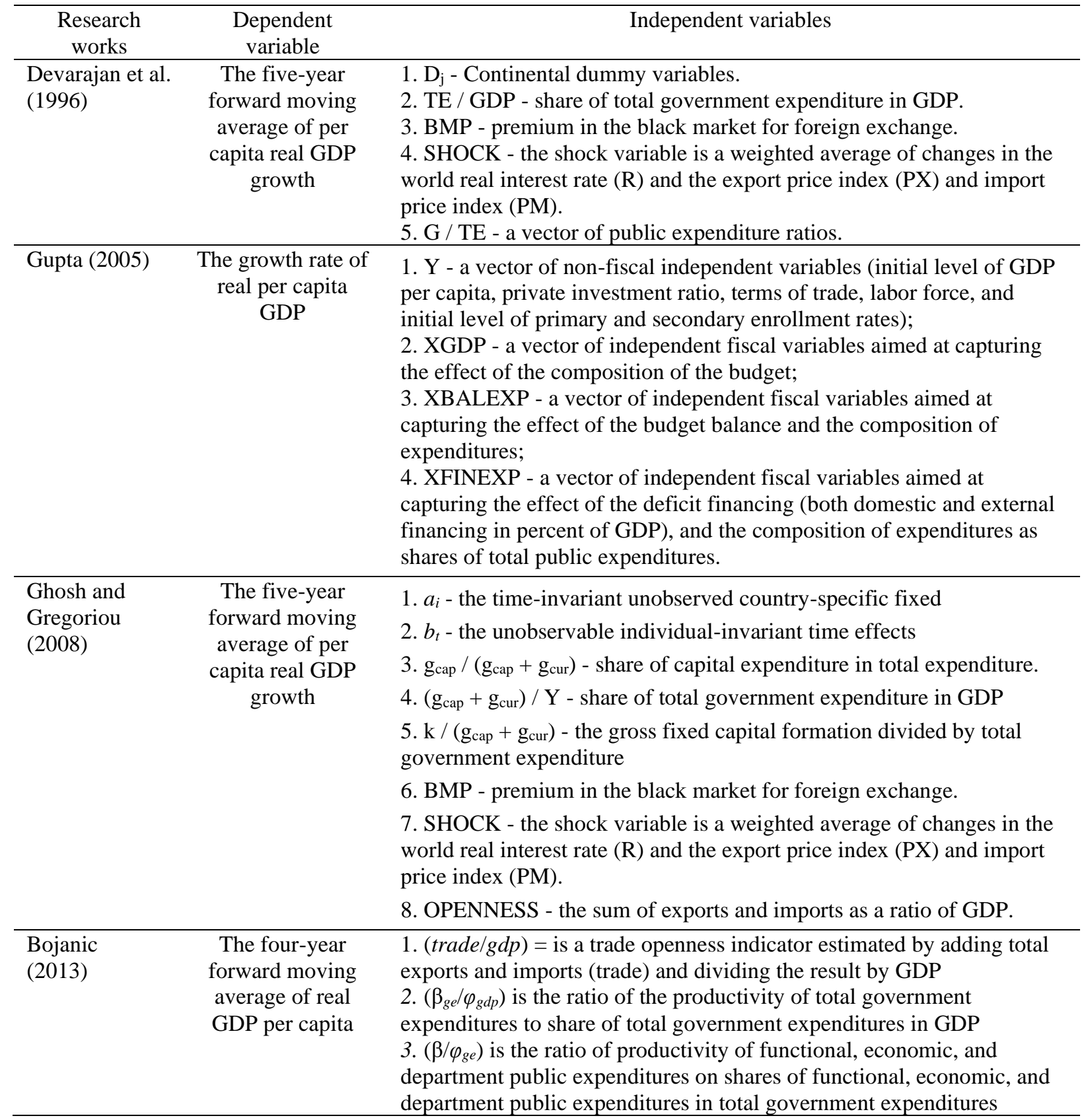




\begin{tabular}{|c|c|c|}
\hline $\begin{array}{l}\text { Neduziak and } \\
\text { Correia (2017) }\end{array}$ & $\begin{array}{c}\text { Difference of the } \\
\log \text { of GDP per } \\
\text { capita }\end{array}$ & $\begin{array}{l}\text { 1. } \mathrm{G} / \mathrm{Y} \\
\text { 2. } \mathrm{G}_{\mathrm{k}} / \mathrm{G} \\
\text { 3. } \mu_{\mathrm{i}} \\
\text { 4. } \theta_{\mathrm{t}} \\
\text { Where: "Y" is the level of GDP, "G" is total government spending and } \\
\mathrm{G}_{\mathrm{k}} \text { is the spending of the } \mathrm{k}^{\text {th }} \text { component; } \mu_{\mathrm{i}} \text { and } \theta_{\mathrm{t}} \text { correspond, } \\
\text { respectively, to the idiosyncratic effect of each state and a dummy } \\
\text { temporal variable. }\end{array}$ \\
\hline
\end{tabular}

Source: own compilation

First of all, we will discuss variables of early empirical works to construct the empirical design of our paper. Therefore, the review of some earlier researches which have been devoted to the impact of the government expenditures on economic growth in Azerbaijan will be helpful. Koeda and Kramarenko (2008) have investigated the impact of government expenditures on economic growth and found that there is a positive impact of public investment on the TFP (total factor productivity). They note that "by the mid-2010s, when the government enters the phase of the fiscal adjustment and cuts back transfers to households, the real non-oil GDP growth also decelerates" (Koeda and Kramarenko, 2008, pp.12). It means that they accept the positive relationship between government consumption and economic growth. Hasanli et. al (2009) investigated the impact of state budget spending on some macroeconomic indicators (inflation, salary, economic growth etc.) in Azerbaijan. Aliyev et al. (2016) found the positive and significant correlation between total budget expenditures and non-oil economic growth for Azerbaijan. But they have not investigated the impact of investment expenditures and consumption expenditures on the non-oil economic growth separately. Aliyev and Nadirov (2016)'s results are similar to Aliyev et al. (2016)'s results. They argued that a $1 \%$ increase in budget expenditures causes an increase of non-oil GDP by $0.55 \%$ in the long-run in Azerbaijan. However, Aliyev and Nadirov (2016) also have not studied the impact of both investment expenditures and consumption expenditures on the non-oil economic growth separately. Aliyev and Mikayilov (2016) investigated the impact of state budget capital expenditures, state budget expenditures for social-cultural activities, other state budget expenditures and oil factor (as oil production and oil price) on the real non-oil GDP by using the ARDL modeling approach for the Azerbaijan economy. They found that the impact of state budget capital expenditures on the real non-oil GDP is insignificant. Moreover, the state budget expenditures for social-cultural activities and other expenses have positive-significant and negative-significant effect, respectively in their model. Hasanov et al. (2016) also have studied the dependence of non-oil GDP on the non-oil employment, capital stock, total government revenues, total government expenditure, local government revenues and local government expenditure. They found that the effect of local government expenditures on non-oil GDP is negative and statistically significant at $10 \%$ significance level. On the base of this result, they argue that fiscal decentralization is harmful for the nonoil sector's growth in Azerbaijan. Further interesting results related to the Azerbaijan economy can be found in Hasanov (2010), Hasanov and Samadova (2010), and Hasanov (2012).

Gurbanov et al. (2017) applied the Johansen co-integration method (by VECM estimate), Fully Modified Ordinary Least Squares Method (FMOLS) and Dynamic Ordinary Least Squares Method (DOLS) to define the co-integration properties of the variables. They found that a $1 \%$ increase in government capital expenditures is associated with a $0.45 \%$, $0.38 \%$ and $0.39 \%$ increase in real non-oil GDP by VECM, FMOLS and DOLS estimates, respectively. Besides that, Abbasov and Aliyev (2018) tested Wagner's law and Keynesian hypothesis in selected Post-Soviet countries and found that there is a long-run relationship 
between total GDP and government expenditures in Azerbaijan. Abbasov (2012, 2013) estimated the dependence of income per capita on the state budget expenditure items. In doing so, Abbasov $(2012,2013)$ didn't use any other explanatory variable, which is the main drawback of the analysis as documented in Aliyev and Mikayilov (2016). Fortunately, Aliyev and Mikayilov (2016) partially solved this problem by using the oil factor as an explanatory variable in their model. The main question of this research is to find the effect of the composition of budget expenditures on the non-oil GDP. In this context, we consider that oil factor is not enough to explain the impact of all foreign shocks. The best delegate for all external shocks is the openness of the economy (see Devarajan et al. (1996), Ghosh and Gregoriou (2008), Bojanic (2013) etc.). Therefore, we will include the openness of the country's economy as a control variable.

Thus, we saw that all above mentioned researches for Azerbaijan support the long-run causal effect running from government spending towards non-oil GDP. Based on these statements, real non-oil GDP (y) will be dependent variable of our empirical model. At the same time, capital stock (k), labor supply (l), state budget capital expenditure (g1), state budget current expenditure (g2) and openness of the country (z) are explanatory variables of our empirical model.

\section{Data set}

Our data set consists of seasonal adjusted real non-oil GDP (y), real capital stock (k), openness of the country (z), state budget seasonal adjusted real capital expenditures (g1), state budget seasonal adjusted real current expenditures (g2) and labor supply (1). All variables have quarterly frequency and cover the period 2005Q1-2021Q1 (65 observations). Descriptive statistics of these variables are given in Table 2.

Table 2. Descriptive statistics of the variables

\begin{tabular}{lcccccc}
\hline & $\begin{array}{c}\mathbf{y}, \\
\text { mln. manats }\end{array}$ & $\begin{array}{c}\mathbf{g}_{1}, \\
\text { mln.manats }\end{array}$ & $\begin{array}{c}\mathbf{g}_{2}, \\
\text { mln. } \\
\text { manats }\end{array}$ & $\begin{array}{c}\mathbf{k}, \\
\text { mln. manats }\end{array}$ & $\begin{array}{c}\text { z, } \\
\text { ratio }\end{array}$ & $\begin{array}{c}\text { l, } \\
\text { thousands }\end{array}$ \\
\hline mean & 6464.63 & 2295.50 & 1227.23 & 90318.12 & 0.66 & 4734.93 \\
\hline st.d & 3414.47 & 1174.31 & 738.35 & 45779.70 & 0.16 & 315.12 \\
\hline min & 974.49 & 362.82 & 55.26 & 27609.44 & 0.42 & 4254.55 \\
\hline max & 12597.81 & 5056.99 & 2798.41 & 184130.21 & 1.03 & 5251.00 \\
\hline
\end{tabular}

Source: own calculation

Quarterly nominal non-oil GDP is taken from the Central Bank of Azerbaijan's Statistic bulletins (Table 1.1) and is converted to the real non-oil GDP by deflator (2007Q2=100). The Non-oil GDP is inferred from the State Statistics Committee and is calculated by subtracting oil-gas industry (oil-gas mining, refinery, oil goods production and services to that industry) from overall GDP. Data on the quarterly capital stock for Azerbaijan (it is called as the basic fixed assets, in source below) is not published. So, we constructed a quarterly capital stock time series with the "perpetual inventory method" by taking capital stock at the end of 2004 (Source: Statistical Yearbook of Azerbaijan 2007, page 344, Table 14.23) as an initial capital stock level, adding quarterly investment (gross fixed capital formation) and deducting about $4.8(\eta=0.048)$ percent of the previous period's capital stock for depreciation. Mathematically, we used equation $\mathrm{K}(\mathrm{t}+1)=(1-\eta) * \mathrm{~K}(\mathrm{t})+\mathrm{I}(\mathrm{t}+1)$ (Braumann, 2016, pp. 100; Rudolf and Zurlinden, 2008) to construct a quarterly capital stock time series. 
Openness of the economy is calculated as a share of the sum of export and import in total GDP. Export and import data were taken from the balance of payment of Azerbaijan Republic (Source: Central Bank of Azerbaijan, External sector statistics). Given that data for export and import are reported in US dollars, we converted them to domestic currency value using the exchange rate AZN/USD for the respective period. (Source: Central Bank of Azerbaijan, Statistic bulletins, Table 2.16).

Quarterly nominal government budget current and capital expenditures are inferred from the Ministry of Finance of the Republic of Azerbaijan (Source: http://www.maliyye.gov.az/en, "Analysis of the performance of budget incomes and expenses") and are converted to the real values by deflator $(2007 \mathrm{Q} 2=100)$. Then, both variables were seasonally adjusted by moving average method. Finally, we use the labor force as an approximation of labor supply (total hours that workers wish to work), which is not available for Azerbaijan (Appendix A and B display the data set used in our analysis graphically).

\section{Methodological approach}

Estimation strategy of the paper consists of two directions. First, all estimation approaches which is described in below were used for the period of 2005Q1-2019Q4. Estimated model for this period is called Model 1. Second, the model which is called Model 2 were estimated for whole period - period of 2005Q1-2021Q1. This approach ensures to compare role of the Government expenditures on non-oil economic activity in normal times and during the COVID-19 pandemic in Azerbaijan. Actually, the COVID-19 pandemic showed its negative impact in Azerbaijan economy after the end of 2019. In 2020, the Government increased the efforts to revive the non-oil economic activity by different fiscal stimulus measures; social programs for households, financial assistance and tax discount for real sector. Approximately, this tendency may create difference between the impact coefficients of the Government expenditures on non-oil economic activity for two different periods.

Methodology of this research consists of both cointegration analysis and generalized method of moments (GMM) to investigate the long-run relationship between non-oil real GDP and explanatory variables which have been introduced in Section 2. Below, we have tried to give short information about these methods:

\section{Cointegration analysis}

Our data set consists of quarterly time series data which usually is non-stationary. We know that the standard regression estimation can be irrelevant if the variables are nonstationary. It means that estimated regression coefficients suggest only spurious information about the correlation between variables (Granger and Newbold, 1974). To avoid this problem, all non-stationary variables can be converted to stationary variables by taking first difference. So, converting the non-stationary variables to stationary, let us to estimate the dependence of response variable on the explanatory variables. But, in this case, we can only investigate the short-run relationship between the variables. Whereas, our main purpose is to study the longrun relationship between the real non-oil GDP and the explanatory variables. In this context, co-integration analysis is a useful tool for the investigation of the long-run relationship (the dynamic relationship) between these economic variables (Johansen-Juselious, 1990; Johansen, 1991). If the variables are non-stationary, but they are co-integrated or they have long-run association, then VECM technique (or restricted VAR technique) should be used for the analysis of both short-run and long-run relationship between these variables. Another challenge is that time series data is not adequately large for Azerbaijan. More specifically, our 
sample size is enclosed between 1991 and 2016, which is short for the noted analysis. For this type of problems, the single equation cointegration method is the better-suited approach to analyze the long-run relationship (Katrakilidis and Tsaliki, 2009). We applied four single equation cointegration analysis methods:

\section{Autoregressive Distributed Lag (ARDL) technique}

In the case of short periods, the Autoregressive Distributed Lag (ARDL) technique (also known as Bound Test) is more appropriate to analyze the long-run relationship (Pesaran and Shin, 1999; Pesaran et al., 2001). The ARDL model with EC (error correction) term can be used to test both, long-run and short-run causality link between variables. Granger et al. (1998) suggested that if EC term is significant at a given confidence level and has correct sign (negative), then there is the long-run causality from the independent variables to the dependent variable. So, we will use ARDL with EC (error correction) term modeling approach to study the long-run causal relationship between independent variables and non-oil GDP instead of the Johansen co-integration test for Azerbaijan. The initial version of this model will be as following:

$$
d \ln y_{t}=\beta_{0}+A(L) d \ln y_{t}+B_{i}(L) d \ln X_{i, t}+\varphi_{1} \ln y_{t-1}+\Psi_{i} \ln X_{i, t-1}+\varepsilon_{t}
$$

Where, $y$ is the real non-oil GDP, $X$ represents a vector of the explanatory variables, $\mathrm{i}$ is the number of explanatory variables, $\mathrm{L}$ is the lag operator, A, B and $\Psi$ are vector of coefficients, $\varepsilon_{t}$ is uncorrelated error terms, $\mathrm{d}$ means the first difference.

ARDL modeling is a single equation estimation technique which is estimated by OLS to co-integration analysis. Therefore, estimated ARDL model must have normality and homoscedasticity assumptions, must be stable and free of serial correlation (Pesaran and Shin, 1999, pp. 4-5).

\section{The results of the ARDL modeling approach}

\section{The integration properties of the variables}

First of all, we must define the integration properties of the variables to apply ARDL technique. Pesaran et al. (2001) introduced critical bound values for variables which are individually $\mathrm{I}(0)$ or $\mathrm{I}(1)$ or mutually cointegrated. For analyzing the integration properties of the variables, we investigated the unit root property in our time series data by using Augmented Dickey-Fuller (ADF) test (Dickey and Fuller, 1979; Dickey and Fuller, 1981). In Table 3, results of the Augmented Dickey-Fuller (ADF) test (unit-root test) for a natural logarithm of the variables has been summarized. Test shows that, the first differences of all logarithmic variables are stationary at the $1 \%$ significance levels for both options (with intercept or with intercept and trend). So, we will work with the first differences of all logarithmic variables with the "intercept and trend" option in the next steps.

\section{Co-integration diagnostic or analysis of the long-run relationship}

In this part we try to investigate whether there is a long-run relationship between seasonal adjusted real non-oil GDP (y) and independent variables (real capital stock (k), openness of the country (z), state budget seasonal adjusted real capital expenditures ( $\mathrm{g} 1)$, state budget seasonal adjusted real current expenditures (g2) and labor supply (l)) using Bound Test (Pesaran et al., 2001) on the base of ARDL testing models. 
Table 3. Unit-root test

\begin{tabular}{lcccc}
\hline Variables & \multicolumn{2}{c}{ with intercept } & \multicolumn{2}{c}{ with intercept and trend } \\
\cline { 2 - 5 } & in level & in the first dif. & in level & in the first dif. \\
\hline $\mathbf{y}$ & -0.73 & $-2.74^{*}$ & $-3.35^{*}$ & -2.70 \\
\hline $\mathbf{g}_{\mathbf{1}}$ & -1.63 & $-10.6^{* * *}$ & -1.96 & $-10.5^{*}$ \\
\hline $\mathbf{g}_{\mathbf{2}}$ & -0.72 & $-10.8^{* * *}$ & -2.16 & $-10.7^{* * *}$ \\
\hline $\mathbf{k}$ & -0.66 & $-6.49^{* * *}$ & -2.93 & $-6.39^{* * *}$ \\
\hline $\boldsymbol{l}$ & 0.08 & $-7.89^{* * *}$ & -3.11 & $-7.84^{* * *}$ \\
\hline $\mathbf{z}$ & -1.81 & $-4.42^{* * *}$ & -2.56 & $-4.41^{* * *}$ \\
\hline
\end{tabular}

Note: The marks *, **, *** represent the significant levels $10 \%, 5 \%$ and $1 \%$, respectively. $y=$ real non-oil GDP, $g_{1}=$ real state budget capital expenditure, $g_{2}=$ real state budget current expenditure, $k$ $=$ real capital stock, $l=$ labor force and $z=$ openness of the country. For more detail about the variables see data section (see Section 2). For analyzing the integration properties of the variables, we investigated the unit root property in our time series data by using Augmented Dickey-Fuller $(A D F)$ test (Dickey and Fuller, 1979; Dickey and Fuller, 1981). Augmented Dickey-Fuller (ADF) procedure has been realized in Eviews. Test shows that, the first differences of all logarithmic variables are stationary at the 1\% significance levels for both options (with intercept or with intercept and trend). So, we will work with the first differences of all logarithmic variables with the "intercept and trend" option in the next steps.

Source: own calculation

\section{Model selection and Bound Test}

In this stage, selection of the best model of our empirical analysis has been fulfilled by the Akaike Information Criterion (AIC) with a max lag length of four quarters, including ARDL models. We checked out some testing equations to detect the optimal lag length for (1) initial ARDL (y, g1, g2, k, l, z) model and summarized some of them which have underline assumptions. The testing procedure for the detecting of the best model was realized for both "intercept and no trend" option and "intercept and trend" option on the base of the Table 3. The results of the model selection and bound test have been given in Table 4. For Model 1, ARDL $(1,0,1,1,1,0)$ is the best model to test the long-run relationship, because it has the lowest value (-1.20) of AIC with a max lag length of one quarter. This model has homoscedasticity, no serial correlation, stability and normality properties. For Model 2, ARDL $(1,1,1,1,0,1)$ is the best model to test the long-run relationship, because it has the lowest value (-1.14) of AIC with a max lag length of one quarter. This model has homoscedasticity, no serial correlation, stability, but doesn't have normality properties.

Now we can estimate long-run relationship between the real non-oil GDP and independent variables by the Bound Test. In other words, we will try to find out whether these variables have long-run relationship or not. Bound Test begins with the null hypothesis that the coefficients of the level variables are jointly equal to zero. We can get the decision on this null hypothesis $-\mathrm{H}_{0}: \varphi_{1}=\Psi=0$ in equation (1) by using $\mathrm{F}$ test. If this calculated value of $\mathrm{F}$ test is greater than upper Pesaran bound value (Pesaran et al., 2001), then we can say that there is a long-run relationship from the explanatory variables towards real non-oil GDP in equation (1). In contrast, if calculated value of $F$ test is less than lower Pesaran bound value, then we can accept the null hypothesis of no co-integration between the variables in equation (1) (Pesaran et al., 2001). So, we found that the null hypothesis $\left(\mathrm{H}_{0}: \varphi_{1}=\Psi=0\right)$ can be rejected for both models on the base of the result of Wald test in Table 4. Because, calculated values of $F$ test for Model $1(\mathrm{~F}(5,59)=9.33)$ and Model $2(\mathrm{~F}(5,64)=6.11)$ greater than Pesaran upper bound value (4.68) for option "Unrestricted intercept and no trend" at $1 \%$ with 5 independent 
variables (see notes of Table 4). On the base of the result of Bound test, we can accept the long-run relationship from the explanatory variables towards the real non-oil GDP in equation (1) for both models. In other words, we can accept that the variables of our models have longrun relationship.

Table 4. Model selection and Bound Test (Intercept and no trend)

\begin{tabular}{|c|c|c|}
\hline \multicolumn{3}{|c|}{ Dependent: DLOG(REAL_NON_OIL_GDP_SA) } \\
\hline & Model 1 & Model 2 \\
\hline DLOG(REAL_CAP_EXP_SA) & ------ & 0.004 \\
\hline DLOG(REAL_CUR_EXP_SA) & 0.14 & 0.16 \\
\hline DLOG(REAL_CAPITAL_STOCK) & $0.75^{* * *}$ & $0.73 * * *$ \\
\hline DLOG(LABOR_FORCE) & ----- & -2.91 \\
\hline DLOG(OPENNESS_SA) & $-0.64 * * *$ & ------ \\
\hline $\mathbf{C}$ & $-29.6 * * *$ & $-22.7 * * *$ \\
\hline LOG(REAL_CAP_EXP_SA(-1)) & $0.08 * *$ & $0.08 * *$ \\
\hline LOG(REAL_CUR_EXP_SA(-1)) & $0.38 * * *$ & $0.41 * * *$ \\
\hline LOG(REAL_CAPITAL_STOCK(-1)) & 0.08 & 0.02 \\
\hline LOG(OPENNESS_SA(-1)) & $-0.39 * *$ & -0.06 \\
\hline LOG(LABOR_FORCE(-1)) & $3.91 * * *$ & $3.03 * * *$ \\
\hline LOG(REAL_NON_OIL_GDP_SA(-1)) & $-0.92 * * *$ & $-0.79 * * *$ \\
\hline \multirow[t]{2}{*}{ Heteroskedasticity Test: BPG } & $\mathrm{F}(9 ; 49)=1.48$ & $\mathrm{~F}(10 ; 53)=1.07$ \\
\hline & Prob. $=(0.18)$ & Prob. $=(0.40)$ \\
\hline \multirow[t]{2}{*}{ Breusch-Godfrey Serial Correlation LM Test } & $\mathrm{F}(1 ; 48)=3.55$ & $F(1 ; 52)=0.82$ \\
\hline & Prob. $=(0.07)$ & Prob. $=(0.37)$ \\
\hline \multirow[t]{2}{*}{ Normality Test } & $\mathrm{JB}=2.24$ & $\mathrm{JB}=12.8$ \\
\hline & Prob. $=(0.33)$ & Prob. $=(0.002)$ \\
\hline Wald test & $\mathrm{F}(5 ; 59)=9.33$ & $\mathrm{~F}(5 ; 64)=6.11$ \\
\hline
\end{tabular}

Notes: Pesaran bound values at 1\% with 5 independent variables for option "Unrestricted intercept and no trend": low=3.41; upper=4.68 (see Pesaran et al. (2001), Table CI(iii) Case III). Normality, homoscedasticity, stability and serial correlation were checked using JB test (Jarque and Bera, 1987), BPG test (Breusch and Pagan, 1979), CUSUM (cumulative sum) test (Page, 1954) and Breusch-Godfrey Serial Correlation LM test (Breusch, 1978; Godfrey, 1978), respectively. The marks $*, * *, * * *$ represent the significant levels $10 \%, 5 \%$ and $1 \%$, respectively.

Source: own calculation

So, ARDL Bounds test statistics provide supporting evidence for existence of cointegration in both equations at $1 \%$ level of significance. Therefore, we can proceed with finding long-run relationship by using equation (2). This co-integrating (long-run) model can be written as following:

$$
\ln y_{t}=c+\delta * d\left(\ln X_{t}\right)+\beta * E C T_{t}+e_{t}
$$

Where, $\mathrm{y}$ is the real non-oil GDP, $\mathrm{X}$ represents a vector of the explanatory variables ( $\mathrm{g} 1=$ real state budget capital expenditure, $\mathrm{g} 2=$ real state budget current expenditure, $\mathrm{k}=$ real capital stock, 1 = labor force and $\mathrm{z}=$ openness of the country), ECT is the error correction term which is obtained from long run equation, $e_{t}$ is uncorrelated error terms, $\mathrm{d}$ means the first difference. For more detail about the variables see data section (see Section 2) in text body. 
Since there is the cointegration among variables (see Table 4), we can estimate the long-run coefficients (elasticities) by running the long-run model (2). The results of estimation of (2) have been given in Table 5 .

Table 5. Estimation of long-run relationship

\begin{tabular}{lcc}
\hline \multicolumn{3}{c}{ Dependent variable: LOG(REAL_NON_OIL_GDP_SA) } \\
\hline & Model 1 & Model 2 \\
\hline & Cointegrating Form & 0.03 \\
\hline DLOG(REAL_CAP_EXP_SA) & $0.06^{* *}$ & 0.12 \\
\hline DLOG(REAL_CUR_EXP_SA) & 0.13 & $0.67^{* * *}$ \\
\hline DLOG(REAL_CAPITAL_STOCK) & $0.68^{* * *}$ & $-0.46^{* * *}$ \\
\hline DLOG(OPENNESS_SA) & $-0.76^{* * *}$ & -1.78 \\
\hline DLOG(LABOR_FORCE) & $3.64^{* * *}$ & $-0.84^{* * *}$ \\
\hline ECT(-1) & $-0.92^{* * *}$ & \\
\hline ECT $=$ LOG(REAL_NON_OIL_GDP_SA) $-\left(0.0755^{*}\right.$ LOG(REAL_CAP_EXP_SA) + \\
0.4085*LOG(REAL_CUR_EXP_SA) + 0.1162*LOG(REAL_CAPITA L_STOCK) \\
0.4678*LOG(OPENNESS_SA) + 3.9663*LOG(LABOR_FORC E) -30.0952$)$ \\
\hline \multicolumn{2}{l}{ Long Run Coefficients } \\
\hline LOG(REAL_CAP_EXP_SA) & $0.08^{* *}$ & $0.11^{* * *}$ \\
\hline DLOG(REAL_CUR_EXP_SA) & $0.41^{* * *}$ & $0.36^{* * *}$ \\
\hline LOG(REAL_CAPITAL_STOCK) & 0.12 & 0.03 \\
\hline DLOG(OPENNESS_SA) & $-0.47^{* *}$ & $-0.54^{* * *}$ \\
\hline LOG(LABOR_FORCE) & $3.97 * * *$ & $4.19^{* * *}$ \\
\hline C & $-30.1 * * *$ & $-30.9^{* * *}$ \\
\hline
\end{tabular}

Note: The marks *,**,*** represent the significant levels $10 \%, 5 \%$ and $1 \%$, respectively. Remain coefficients are insignificant.

Source: own calculation

So, as seen in the Table 5, the coefficients of the ECT are less than one, negative and statistical significant for both models. It means that, there is long-run causality from explanatory variables to dependent variable. On the base of this result the long-run coefficients in Table 5 can be used to explain the long run relationship. These coefficients will be discussed in "Discussion" section (see Section 4) in the text. In below, we have tried to discussed three alternative cointegration analysis methods.

Alternative cointegration analysis methods

Fully Modified OLS (FMOLS)

We also use FMOLS method, which has been introduced by Phillips and Hansen (1990) as an alternative to investigate the long-run relationship between our variables. This method can reach decent estimates for small sample size. Moreover, for testing single equation co-integrating relationship, this method can be useful and it is a non-parametric approach used to deal with serial correlation. We can write FMOLS co-integrating equation as following:

$$
\ln Y_{t}=\beta_{0}+\beta_{i} \ln X_{i t}+\gamma \ln D_{1 t}+\varepsilon_{t}
$$

Where, $X_{i t}=\alpha_{1 i} D_{1 t}+\alpha_{2 i} D_{2 t}+\epsilon_{t}$. $\mathrm{D}_{1 \mathrm{t}}$ and $\mathrm{D}_{2 \mathrm{t}}$ are deterministic trend regressors, $\mathrm{X}_{\mathrm{it}}$ are the stochastic regressor, $X$ represents the explanatory variables, $i$ is the number of 
explanatory variables. For more detailed mathematical properties of the FMOLS see Phillips and Hansen (1990).

\section{Canonical Co-Integrating Regression (CCR)}

The Canonical Co-Integrating Regression (CCR) approach which was developed by Park (1992) is one of the cointegration analysis methods. It looks like FMOLS method, but there is a difference between these two approaches. Removing the long run dependence between the co-integrating equation and stochastic regressors innovations are used instead of working on stationary transformations of the data in CCR. For more detailed mathematical properties of the CCR see Park (1992).

\section{Dynamic OLS (DOLS)}

DOLS method has been advocated by Saikkonen (1992) and Stock and Watson (1993). It is a useful approach that eliminates the feedback in the co-integrating system. The trend assumptions and the lag and lead specification are properties of this approach. For more detailed mathematical properties of the Dynamic OLS (DOLS) see Saikkonen (1992) and Stock and Watson (1993).

\section{The results of other alternative cointegration analysis methods}

In above, we analyzed cointegration relationship between variables and estimated the long-run coefficients by using the ARDL modeling approach. Here, the results of three alternative cointegration analysis methods (FMOLS, CCR and DOLS) are given (see Table $6)$.

Table 6. The estimation results of alternative cointegration analysis methods

\begin{tabular}{|c|c|c|c|c|c|c|c|c|c|c|c|c|}
\hline & \multicolumn{4}{|c|}{ FMOLS } & \multicolumn{4}{|c|}{ CCR } & \multicolumn{4}{|c|}{ DOLS } \\
\hline & \multicolumn{2}{|c|}{ Model 1} & \multicolumn{2}{|c|}{ Model 2} & \multicolumn{2}{|c|}{ Model 1} & \multicolumn{2}{|c|}{ Model 2} & \multicolumn{2}{|c|}{ Model 1} & \multicolumn{2}{|c|}{ Model 2} \\
\hline & Trend & $\begin{array}{l}\text { No } \\
\text { trend }\end{array}$ & Trend & $\begin{array}{l}\text { No } \\
\text { trend }\end{array}$ & Trend & $\begin{array}{l}\text { No } \\
\text { trend }\end{array}$ & Trend & $\begin{array}{l}\text { No } \\
\text { trend }\end{array}$ & Trend & $\begin{array}{l}\text { No } \\
\text { trend }\end{array}$ & Trend & No trend \\
\hline $\ln \left(g_{1}\right)$ & $0.12^{* * *}$ & $0.13^{* * *}$ & $0.12^{* * * *}$ & $0.12^{* * *}$ & $0.10^{* * *}$ & $0.10^{* * *}$ & $0.10^{* * * *}$ & $0.09^{* * * *}$ & $0.11^{* * *}$ & $0.11^{* * *}$ & $0.12^{* * *}$ & $0.11^{* * *}$ \\
\hline $\ln \left(g_{2}\right)$ & $0.22^{* * *}$ & $0.22^{* *}$ & $0.28^{* * * *}$ & $0.28^{* * *}$ & $0.37^{* * * *}$ & $0.36^{* * *}$ & $0.39^{* * * *}$ & $0.36^{* * * *}$ & $0.43^{* * *}$ & $0.41^{* * *}$ & $0.44^{* * * *}$ & $0.40^{* * * *}$ \\
\hline $\ln (\mathbf{k})$ & $0.24^{*}$ & $0.21^{*}$ & $0.32^{* * * *}$ & $0.26^{* *}$ & $0.34^{* * * *}$ & $0.40^{* * *}$ & $0.41^{* * * *}$ & $0.51^{* *}$ & -0.01 & -0.05 & 0.08 & -0.01 \\
\hline $\ln (l)$ & 2.94 & $3.73^{* * *}$ & $5.20^{* * *}$ & $2.89^{* * * *}$ & $3.88^{*}$ & $2.11^{* * *}$ & $6.08^{* * *}$ & 1.01 & $6.93^{* * *}$ & $4.96^{* *}$ & $8.60^{* * * *}$ & $4.43^{* *}$ \\
\hline $\ln (z)$ & $-0.68^{* * * *}$ & $-0.69^{* * *}$ & $-0.52^{* * *}$ & $-0.57^{* * *}$ & $-0.26^{* *}$ & -0.18 & -0.18 & -0.09 & $-0.47^{* *}$ & $-0.52^{* *}$ & $-0.40^{*}$ & $-0.50^{* *}$ \\
\hline C & -21.9 & $-28.3^{* * *}$ & $-41.9^{* * * *}$ & $-21.9^{* * *}$ & -31.4 & $-17.3^{* * * *}$ & $-50.6^{* *}$ & $-9.14^{* * *}$ & $-53.9^{* *}$ & $-36.9^{* *}$ & $-68.8^{* * * *}$ & $-32.9^{* *}$ \\
\hline @ trend & 0.002 & ------- & -0.009 & ------- & -0.005 & ------ & $-0.02^{*}$ & ----- & -0.01 & ----- & -0.02 & ----- \\
\hline$R^{2}$ & 0.96 & 0.96 & 0.96 & 0.96 & 0.95 & 0.95 & 0.96 & 0.95 & 0.98 & 0.98 & 0.98 & 0.98 \\
\hline Wald test & $\begin{array}{l}\mathrm{F}(5,52)^{* * *}, \\
\chi^{2}(5)^{* * *},\end{array}$ & $\begin{array}{c}\mathrm{F}(5,53)^{* * * *}, \\
\chi^{2}(5)^{* * *},\end{array}$ & $\begin{array}{c}\mathrm{F}(5,57)^{* * * *}, \\
\chi^{2}(5)^{* * *}\end{array}$ & $\begin{array}{c}\mathrm{F}(5,58)^{* * * *}, \\
\chi^{2}(5)^{* * *}\end{array}$ & $\begin{array}{c}\mathrm{F}(5,52)^{* * *}, \\
\chi^{2}(5)^{* * *}\end{array}$ & $\begin{array}{c}\mathrm{F}(5,53)^{* * * *}, \\
\chi^{2}(5)^{* * * *}\end{array}$ & $\begin{array}{c}\mathrm{F}(5,57)^{* * * *}, \\
\chi^{2}(5)^{* * *}\end{array}$ & $\begin{array}{c}\mathrm{F}(5,58)^{* * *}, \\
\chi^{2}(5)^{* * *},\end{array}$ & $\begin{array}{c}\mathrm{F}(5,36)^{* * * *}, \\
\chi^{2}(5)^{* * *}\end{array}$ & $\begin{array}{c}\mathrm{F}(5,37)^{* * * *}, \\
\chi^{2}(5)^{* * *}\end{array}$ & $\begin{array}{c}\mathrm{F}(5,40)^{* * * *}, \\
\chi^{2}(5)^{* * *}\end{array}$ & $\begin{array}{c}\mathrm{F}(5,41)^{* * *}, \\
\chi^{2}(5)^{* * *}\end{array}$ \\
\hline $\begin{array}{l}\text { Properties of } \\
\text { cointegration } \\
\text { equations }\end{array}$ & \multicolumn{4}{|c|}{$\begin{array}{l}\text { Properties of FMOLS: Regressor equations } \\
\text { estimated using differences. Long-run } \\
\text { covariance estimate (Prewhitening with lags } \\
=1 \text { from AIC maxlags }=3 \text {, Bartlett kernel, } \\
\text { Newey-West fixed bandwidth }=4.0000 \text { ); } \\
\text { cointegrating equation deterministic }-\mathrm{C} \\
\text { (intercept) and trend; there is no additional } \\
\text { deterministic regressors }\end{array}$} & \multicolumn{4}{|c|}{$\begin{array}{l}\text { Properties of CCR: Regressor equations } \\
\text { estimated using differences. Long-run } \\
\text { covariance estimate (Prewhitening with lags } \\
=1 \text { from AIC maxlags }=3 \text {, Bartlett kernel, } \\
\text { Newey-West fixed bandwidth }=4.0000 \text { ); } \\
\text { cointegrating equation deterministic }-\mathrm{C} \\
\text { (intercept) and trend; there is no additional } \\
\text { deterministic regressors }\end{array}$} & \multicolumn{4}{|c|}{$\begin{array}{l}\text { Properties of DOLS: Fixed leads and lags } \\
\text { specification (lead=1, lag=1) HAC standard } \\
\text { errors \& covariance }(\text { Bartlett kernel, Newey- } \\
\text { West fixed bandwidth }=4.0000) \text {; } \\
\text { cointegrating equation deterministic - C }\end{array}$} \\
\hline
\end{tabular}

We can see that F-statistic and chi-square statistic are significant at $1 \%$ percent level in Wald test. This result lets us to reject the null hypothesis of $\mathrm{C}(1)=\mathrm{C}(2)=\mathrm{C}(3)=\mathrm{C}(4)=\mathrm{C}(5)=1$. It means that, all alternative cointegration equations support the long-run relationship between variables. Moreover, trend factor is insignificant in all cointegration equations and therefore, we will use the results of the cointegration equations with no trend specification for discussion in "Discussion" section (see Section 4) in the text.

\section{Generalized method of moments (GMM)}

Besides cointegration analysis, GMM is also powerful method to investigate the longrun relationship between government expenditures and economic growth by econometric 
analysis. Usually, the five-period or four-period (year, quarter or month) forward moving average of dependent variable is used to investigate the long-run relationship between government expenditures and economic growth. We also used five-year forward moving average of real non-oil GDP as the dependent variable of our empirical model. Such kind of construction of dependent variables allow us to avoid the lag and lead effects of the variables and to increase sample size (Devarajan et al.,1996; Ghosh and Gregoriou, 2008; Bojanic, 2013). We estimated mentioned relationship by GMM which was developed by Hansen (1982) to avoid possible serial correlation problem in the error terms.

\section{The results of Generalized method of moments (GMM)}

In previous subsections we estimated the cointegration equations by using the both ARDL modeling approach and three alternative cointegration analysis methods. In this subsection, the results of GMM have been presented in Table 7.

Table 7. The result of GMM

\begin{tabular}{lcc}
\hline & Model 1 & Model 2 \\
\hline $\ln \left(\boldsymbol{g}_{\mathbf{1}}\right)$ & $0.05 *$ & $0.05^{*}$ \\
\hline $\ln \left(\boldsymbol{g}_{\mathbf{2}}\right)$ & $0.39 * * *$ & $0.39 * * *$ \\
\hline $\ln (\mathbf{k})$ & $0.34 * * *$ & $0.34 * * *$ \\
\hline $\ln (\boldsymbol{l})$ & $3.13 * * *$ & $2.74 * * *$ \\
\hline $\ln (\mathbf{z})$ & $-0.31 * * *$ & $-0.29 * * *$ \\
\hline $\mathbf{C}$ & $-25.1 * * *$ & $-21.9 * * *$ \\
\hline $\mathbf{R}^{\mathbf{2}}$ & 0.98 & 0.98 \\
\hline Adjusted $\mathbf{R}^{\mathbf{2}}$ & 0.97 & 0.97 \\
\hline
\end{tabular}

Notes: Estimation weighting matrix: White. Standard errors \& covariance computed using White weighting matrix. Instrument specification: $\ln \left(g_{1}\right), \ln \left(g_{2}\right), \ln (k), \ln (l)$ and $\ln (z)$. Constant added to instrument list. Three-years forward moving average of real non-oil GDP is dependent variable. $y=$ real non-oil GDP, $g_{1}=$ real state budget capital expenditure, $g_{2}=$ real state budget current expenditure, $k=$ real capital stock, $l=$ labor force and $z=$ openness of the country. $* * *, * *$ and $*$ indicate significance of the coefficients at the 1\%, 5\% and 10\% significance levels, respectively.

Source: own calculation

\section{Discussion and conclusion}

We estimated five long-run equations (Table 5, Table 6 and Table 7), and all results display that, there is a long-run relationship between variables. According to the main question of our research we have to find the impact of Government's capital and current expenditures on non-oil economic activity. As seems, coefficient of capital expenditures is equal approximately to 0.10 for the both periods; 2005Q1-2019Q4 and 2005Q1-2021Q1 in ARDL (Table 5), FMOLS, CCR and DOLS (Table 6). But, in GMM equation (Table 7) this coefficient is equals to 0.05 for both periods. Four out of five estimation methods suggest impact coefficient as 0.10 for capital expenditures. As seems from the tables, the coefficient of current expenditures is equal approximately to 0.40 for the period of 2005Q1-2019Q4 and period of 2005Q1-2021Q1 in ARDL (Table 5), CCR, DOLS (Table 6) and GMM (Table 7). But, in FMOLS equation (Table 6) this coefficient is equals approximately to 0.2 for the period of 2005Q1-2019Q4 while it is equals approximately to 0.3 for the period of 2005Q12021Q1. So, four out of five long-run equations suggest 0.40 for the coefficient of state budget current expenditures. As a result, we already can interpret that 1 percent increase in capital expenditures of state budget increases the real non-oil GDP by 0.10 percent. Simultaneously, 1 percent growth in current expenditures enhances real non-oil GDP by 0.40 percentage points. Consequently, capital expenditures and current expenditures of government budget have positive impact on the real non-oil GDP in Azerbaijan. 
From policy making perspective research shows that current expenditures have higher multiplier effect than capital outlays. One of the explanations might be that marginal propensity to consume is higher. Hence in case of crisis it will be appropriate to keep current expenditures and cut capital expenditures in order to support economic activity.

Here, we try to compare our results about Government capital and current expenditures with some of early empirical researches in this field. For instance;

Devarajan et al. (1996) has found a negative (positive) relationship between capital expenditure and GDP growth, and positive (negative) relationship between current expenditures and GDP growth in developing (developed) countries by linear specification models. By using nonlinear specification models, Devarajan et al. (1996) found that both capital and current expenditures have a positive impact on GDP growth rate (Devarajan et al., 1996, Table 4). In our opinion, this result of Devarajan et al. (1996) is in compliance with our findings.

Public investment spending was found to be productive, having a positive impact on economic growth in developing countries by Easterly and Rebelo, which is also in line with our findings (Easterly and Rebelo, 1993).

Our results about capital expenditures of the state budget is similar to the findings of Gupta (2005), who reported that capital expenditures have positive impact on economic growth in low-income countries. In addition, Gupta (2005) found that current expenditures have a negative impact on economic growth in low-income countries and it is in contrast with our result about the current expenditures of state budget.

Ghosh and Gregoriou (2008) used three methods (OLS fixed effects, GMM single equation, GMM system) to estimate the relationship between government capital and current expenditures and per capita real GDP growth. They found that government's capital spending has negative impact (in contrast with our result) on per capita real GDP growth, while government's current spending influences positively (in compliance with our finding) per capita real GDP growth for both, high- and low-income countries.

Bojanic (2013) found that current expenditures of central government are productive (has the positive impact on GDP per capita) while capital expenditure of central government is unproductive (has the negative impact on GDP per capita) in Bolivia.

Narvaez (2012) estimated six models by using GMM two-step method to analysis the relationship between government capital and current expenditures and economic growth (per capita GDP growth) in developing countries of the Latin America. He found positive relationship between both types of government expenditures (capital and current) and per capita GDP growth in four out of six (negative relationship rest two models) models (Narvaez, 2012, Table 1). Note that, our results on capital and current expenditures of state budget are also compliant with Narvaez (2012)'s results.

Marica (2015) has investigated the link between the composition of government spending and economic growth in Italy using four models. On the one hand, the study reported that there is a positive effect of the government capital expenditure on the GDP percapita growth in all estimated models (Marica, 2015, Table 1). On the other hand, the study reports a negative effect of the government current expenditures on the GDP per-capita growth rate in three out of four models (Fixed Effects, IV-DIFF, GMM-DIFF) while this relationship is positive in one (GMM-SYS) of these models (Marica, 2015, Table 1).

We found that the elasticity coefficient of the real capital stock $(\mathrm{k})$ is negative for GMM and it is equal to -0.50 , while it is positive for all other estimation methods and approximately equal to 0.40 . The elasticity coefficients of the state budget seasonal adjusted real capital expenditures (g1) is positive and approximately equal to 0.10 for all estimation methods. The elasticity coefficients of the state budget seasonal adjusted real current expenditures (g2) is positive for all approaches, but the coefficients differ. Using the ADRL, 
the FMOLS, and the CCR technique, the coefficient is approximately equal to 0.30 . For DOLS and GMM, we find the coefficient to be approximately equal to 0.50 . The elasticity coefficients controlling for the openness of the country $(\mathrm{z})$ is negative in all equations, but the size of the coefficient varies among estimation methods: it is approximately equal to -0.40 and is statistically significant for the ARDL, the FMOLS, and the CCR model, while it is approximately equal to -0.50 and statistically significant using GMM. Note that, this coefficient was insignificant in DOLS. The elasticity coefficients of the labor supply (1) is also found to be insignificant in DOLS. It is approximately equal to 2.0 and is statistically significant using the ARDL, the FMOLS and the CCR technique. For GMM, the estimate of this coefficient is equal to 5.64 and significant.Another interesting result of our estimation is that, almost in all estimation methods openness of economy (z) has negative sign. This states that expansion of economic openness decreases non-oil economic growth in Azerbaijan. Possible explanation is that, this country possesses very low non-oil export (everlasting large negative non-oil trade balance), and openness mostly caused by increase in import volume which diminishes non-oil GDP.

\section{Results}

This paper documents that the capital expenditures and the current expenditures of the government budget have a positive impact on the real non-oil GDP for Azerbaijan. We found that 1 percent increase in capital expenditures of government budget increases the real non-oil GDP by 0.10 percentage points in Azerbaijan. Same elasticity coefficient for current expenditures is 0.40 percentage points. Main difference of our finding is that coefficient of both, capital expenditures and current expenditures of the government budget are positive for Azerbaijan.

The literature says that, increasing current expenditures are usually financed by higher taxes, which causes a lagged decrease in the private investment. As a result, the literature concludes that there is a negative impact of increasing current expenditures on economic growth. However, Azerbaijan has a different state budget revenue system, which is primarily financed by non-tax sources. During our observation period 2005Q1-2021Q1, lion share of increasing government expenditures was financed by the transfers from the State Oil Fund. On the base of this statement we say that, positive impact of capital and current expenditures of government budget on non-oil GDP seems plausible for Azerbaijan.

Another interesting result of our estimation is that, expansion of economic openness decreases non-oil economic growth in Azerbaijan. We interpret this paradox with very low non-oil export volume of the country, where openness mostly caused by increase in import volume.

One of the main findings of the study is the impact of the COVID19 pandemic on the long-term relationship between Azerbaijan's government spending and the non-oil economic growth. To achieve this result, the observation period was divided into two parts. The first part covers the period before the pandemic - 2005Q1-2019Q4, and the second part covers the period 2005Q1-2021Q1 and covers the full observation period, including the pandemic. Results show that the coefficients characterizing the impact of government's current and capital expenditures on non-oil economic growth are almost identical for both periods. Thus, the COVID19 pandemic did not affect the structure of the relationship between government current and capital expenditures and non-oil economic growth. 


\section{Acknowledgement}

We would like to thank Mr. Benedikt Braumann (IMF, SECO) and Benjamin Müller (Swiss National Bank and University of Zürich) for their contributions, as well as Economists at the Central Bank of Azerbaijan Ms. Aytan Akhundova and Mr. Nabi Rustamli for editorial support.

\section{References}

Abbasov, J. (2012). Econometric estimation of influence of budget expenses to income per capita and optimal distribution of budget expenses. Transactions of Azerbaijan National Academy of Sciences, series of physical-technical and mathematical sciences, XXXII(6), 123-132.

Abbasov, J. (2013). Optimum Budget Expenditures Having a Maximum influence on the Personal Income Per Capita. The Case of Azerbaijan. ECO2013-International Conference on Energy, Regional Integration and Socio-Economic Development, Baku, Azerbaijan, 5-6 September

Abbasov, J., \& Aliyev, K. (2018). Testing Wagner's law and Keynesian hypothesis in selected Post-Soviet countries. Acta Univ. Agric. Silvic. Mendelianae Brun., 66, 12271237.

Aliyev, K. and Mikayilov, C. (2016). Does the budget expenditure composition matter for long-run economic growth in a resource rich country? Evidence from Azerbaijan. Academic Journal of Economic Studies, 2(2), pp.147-168.

Aliyev, K., \& Nadirov, O. (2016). How fiscal policy affects non-oil economic performance in Azerbaijan? Academic Journal of Economic Studies, 2(3), pp.11-29.

Aliyev, K., Dehning, B., \& Nadirov, O. (2016). Modelling the impact of fiscal policy on nonoil GDP in a resource rich country: evidence from Azerbaijan. Acta Universitatis Agriculturae et Silviculturae Mendelianae Brunensis, 64(6), 1869-1878.

Arrow, K. J., \& Kurz, M. (1970). Public Investment, the Rate of Return and Optimal Fiscal Policy. Johns Hopkins University, Baltimore, MD.

Barro, R. J. (1990). Government Spending in a Simple Model of Endogeneous Growth. Journal of Political Economy, 98(5), S103-S125

Bojanic, A. N. (2013). The Composition of Government Expenditures and Economic Growth in Bolivia. Latin American Journal Of Economics, 50(1), 83-105

Braumann, B. (2004). High Inflation and Real Wages. IMF Staff Papers, 51(1), 123-147

Braumann, B. (2016). Macroeconomic Planning for Governments (Principles of Financial Programming). SECO

Breusch, T. S., \& Pagan, A. R. (1979). A Simple Test for Heteroscedasticity and Random Coefficient Variation. Econometrica, 47(5), 1287-1294.

Chakravarty, S. (1962). Optimal Savings with Finite Planning Horizon. International Economic Review, 3(3), 338-355.

Chappell, D. (1977). Optimal growth with logarithmic utility. Recherches Économiques de Louvain / Louvain Economic Review, 43(2), 165-172

Chen, B. L. (2006). Economic Growth with an Optimal Public Spending Composition. Oxford Economic Papers, 58(1), 123-136

Devarajan, S., Swaroop, V., \& Zou, H. (1996). The composition of public expenditure and economic growth, Journal of Monetary Economics, 37, 313-344

Dickey, D. A., \& Fuller, W. A. (1979). Distribution of the Estimators for Autoregressive Time Series with a Unit Root. Journal of the American Statistical Association, 74,(366), $427-431$ 
Dickey, D. A., \& Fuller, W. A. (1981). Likelihood Ratio Statistics for Autoregressive Time Series with a Unit Root. Econometrica, 49(4), 1057-1072

Easterly, W., \& Rebelo, S. (1993). Fiscal policy and economic growth: An empirical investigation. Journal of Monetary Economics, 32, 417-458

Futagami, K., Morita, Y., \& Shibata, A. (1993). Dynamic Analysis of an Endogenous Growth Model with Public Capital. The Scandinavian Journal of Economics, 95(4), 607-625

Ghosh, S., \& Gregoriou, A. (2008). The Composition of Government Spending and Growth: Is Current or Capital Spending Better? Oxford Economic Papers, New Series, 60(3), 484-516

Granger, C. W. J., \& Newbold, P. (1974). Spurious regressions in econometrics. Journal of Econometrics, 2(2), 111-120

Gurbanov, S., Nugent, J. B., \&Mikayilov, J. (2017). Management of Oil Revenues: Has That of Azerbaijan Been Prudent? Economies, 5(2), 19; doi:10.3390/economies5020019

Hansen, L. P. (1982). Large Sample Properties of Generalized Method of Moments Estimators. Econometrica, 50(4), 1029-1054

Hasanli, Y., Bulut, C., Valiyev, V., \& Baxışov N. (2009). Bütçe harclama kanallarının sosyoekonomik kalkınma göstergelerine etkisi. X Ekonometri ve istatistik sempozyumu bildiriler özet kitapçı̆̆l, Erzurum, Ataturk Unversitesi/Türkiye, 27-29 Mayıs

Hasanov, F. (2010). The Impact of Real Oil Price on Real Effective Exchange Rate: The Case of Azerbaijan. DIW Berlin, German Institute for Economic Research. Discussion Paper Series 1041, Available from: http://www.diw.de/documents/publikationen/73/diw_01.c.359129.de/dp1041.pdf.

Hasanov, F. (2012). The Impact of the Real Exchange Rate on Non-oil Exports. Is There an Asymmetric Adjustment towards the Equilibrium?. In: The Working Paper Series of Research Program on Forecasting The Department of Economics, The George Washington University. No. 05. Available from: http://www.gwu.edu/wforcpgm/2012005.pdf.

Hasanov, F. (2013). Dutch disease and the Azerbaijan economy. Communist and PostCommunist Studies, 46, 463-480.

Hasanov, F., \& Samadova, I. (2010). The impact of real effective exchange rate on the non-oil export: The case of Azerbaijan. ECO Econ. J., 2, 23-39.

Hasanov, F., Mikayilov, C., Yusifov, S., \& Aliyev, K. (2016). Impact of Fiscal Decentralization on Non-Oil Economic Growth in a Resource Rich Economy. Eurasian Journal of Business and Economics, 9 (17), 87-108.

Huseynov, S., \& Ahmadov, V. (2013). Oil Windfalls, Fiscal Policy and Money Market Disequilibrium. William Davidson Institute, Working Paper Number 1051.

Katrakilidis, C. and Tsaliki, P. (2009). Further evidence on the causal relationship between government spending and economic growth: The case of Greece, 1958-2004. Acta Oeconomica, 59(1), 57-78

Koeda, J., \& Kramarenko, V. (2008). Impact of Government Expenditure on Growth: The Case of Azerbaijan. IMF Working Paper, WP/08/115.

Marica, S. (2015). Essays on the Composition of Government Spending and Economic Growth. Doctoral research work, SSD SECS-P/01, University of Cagliari.

Narvaez, R. A. C. (2012). The composition of government spending and economic growth in developing countries: The case of latin america. OIDA International Journal of Sustainable Development, 05: 06

Neduziak, L. C. R., \& Correia, F. M. (2017). The allocation of government spending and economic growth: a panel data study of Brazilian states. Revista de Administracao Publica (Revista de Administração Pública), 51(4), 616-632, DOI: http://dx.doi.org/10.1590/0034-7612155177 
Park, J. Y. (1992). Canonical Cointegrating Regressions. Econometrica, 60, 119-143

Pesaran, H. M., \& Shin, Y. (1999). An Autoregressive Distributed Lag Modelling Approach to Cointegration Analysis. doi=10.1.1.153.3246

Pesaran, H. M., Shin, Y., \& Smith, R. J. (2001). Bounds Testing Approaches to the Analysis of Level Relationships. Journal of Applied Econometrics, 16(3), 289-326

Ramsey, F. P. (1928). A Mathematical Theory of Saving. The Economic Journal, 38(152), 543-559.

Rudolf, B., \& Zurlinden, M. (2008). Measuring capital stocks and capital services in Switzerland. Swiss National Bank Working Papers, 11.

Saikkonen, P. (1992). Estimation and Testing of Cointegrated Systems by an Autoregressive Approximation. Econometric Theory, 8, 1-27.

Stock, J. H., \& Watson, M. (1993). A Simple Estimator Of Cointegrating Vectors In Higher Order Integrated Systems. Econometrica, 61, 783-820.

Wooldridge, J. (2001). Applications of generalized method of moments estimation. Journal of Economic Perspectives, 15(4), 87-100. 


\section{Appendix A}
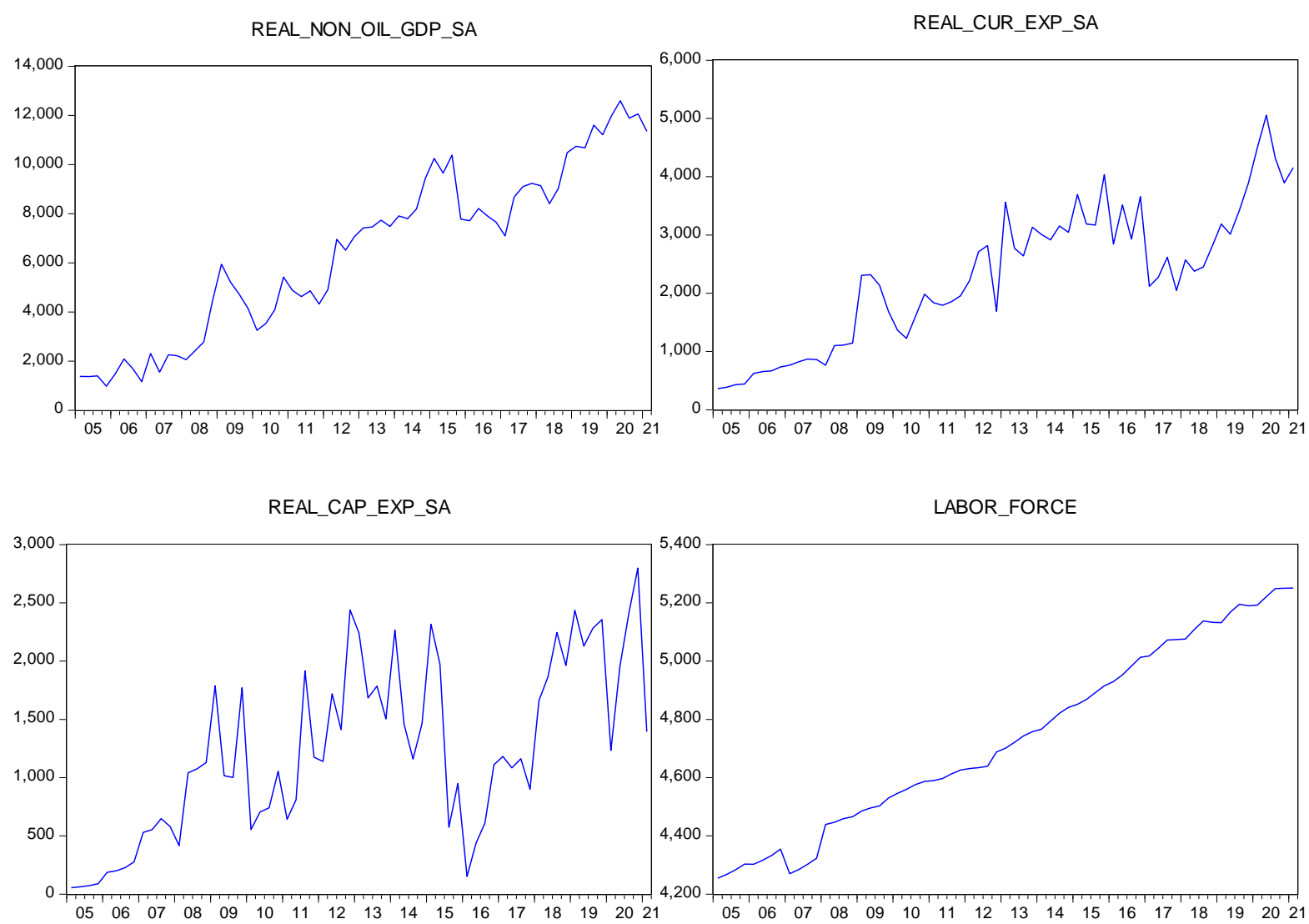

OPENNESS_SA

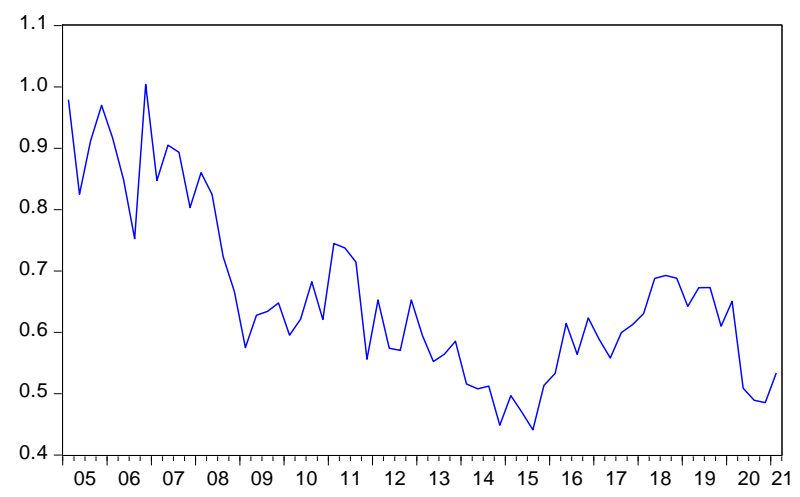

Figure A1. Illustration for the variables 


\section{Appendix B}

Table B1. Data set

\begin{tabular}{|c|c|c|c|c|c|c|}
\hline Date & $\begin{array}{c}\text { Seasonal } \\
\text { adjusted real } \\
\text { non oil GDP } \\
(2017 Q 2=100)\end{array}$ & $\begin{array}{c}\text { Seasonal adjusted } \\
\text { Real Current } \\
\text { Expenditure, mln. } \\
\text { manats }\end{array}$ & $\begin{array}{c}\text { Seasonal } \\
\text { adjusted Real } \\
\text { Capital } \\
\text { Expenditure, } \\
\text { mln. manats } \\
\end{array}$ & $\begin{array}{l}\text { Real } \\
\text { capital } \\
\text { stock, mln. } \\
\text { manats }\end{array}$ & Openness & $\begin{array}{c}\text { Labor } \\
\text { force, } \\
\text { thousands }\end{array}$ \\
\hline 2005Q1 & 1376.00 & 362.82 & 55.26 & 27609.44 & 1.03 & 4254.5 \\
\hline $2005 \mathrm{Q} 2$ & 1367.72 & 385.04 & 62.71 & 28381.58 & 0.93 & 4267.5 \\
\hline $2005 Q 3$ & 1396.84 & 429.05 & 72.79 & 29218.78 & 0.97 & 4283.5 \\
\hline $2005 Q 4$ & 974.49 & 442.49 & 88.94 & 28875.45 & 0.77 & 4303.2 \\
\hline 2006Q1 & 1478.42 & 622.69 & 186.49 & 32822.95 & 0.96 & 4302.4 \\
\hline $2006 Q 2$ & 2083.37 & 655.58 & 199.87 & 35386.51 & 0.96 & 4316.2 \\
\hline $2006 Q 3$ & 1689.30 & 665.09 & 226.87 & 34686.75 & 0.80 & 4332.9 \\
\hline $2006 Q 4$ & 1164.10 & 733.70 & 276.72 & 35587.33 & 0.80 & 4354.4 \\
\hline 2007Q1 & 2310.17 & 764.98 & 530.13 & 38043.65 & 0.88 & 4270.1 \\
\hline 2007Q2 & 1549.02 & 822.88 & 553.58 & 39732.83 & 1.03 & 4284.3 \\
\hline $2007 Q 3$ & 2261.39 & 871.11 & 648.43 & 40925.17 & 0.95 & 4302.3 \\
\hline $2007 Q 4$ & 2216.05 & 862.12 & 580.48 & 38221.07 & 0.64 & 4323.1 \\
\hline 2008Q1 & 2056.92 & 763.82 & 416.71 & 32543.00 & 0.89 & 4439.0 \\
\hline 2008Q2 & 2419.24 & 1100.19 & 1041.69 & 35122.38 & 0.94 & 4447.0 \\
\hline 2008Q3 & 2777.75 & 1111.29 & 1074.52 & 36490.81 & 0.77 & 4459.0 \\
\hline $2008 Q 4$ & 4469.69 & 1144.74 & 1129.95 & 40314.31 & 0.53 & 4466.0 \\
\hline 2009Q1 & 5938.04 & 2306.20 & 1787.90 & 73497.23 & 0.60 & 4485.0 \\
\hline 2009Q2 & 5215.13 & 2319.96 & 1015.29 & 83072.12 & 0.71 & 4496.0 \\
\hline 2009Q3 & 4715.03 & 2135.51 & 1000.60 & 79846.05 & 0.67 & 4503.0 \\
\hline 2009Q4 & 4133.89 & 1687.23 & 1770.58 & 71997.66 & 0.52 & 4530.0 \\
\hline 2010Q1 & 3250.00 & 1366.02 & 554.71 & 42962.27 & 0.63 & 4546.0 \\
\hline $2010 Q 2$ & 3527.75 & 1225.23 & 703.49 & 47241.78 & 0.69 & 4560.0 \\
\hline 2010Q3 & 4078.90 & 1606.20 & 741.57 & 52629.58 & 0.71 & 4576.0 \\
\hline $2010 Q 4$ & 5415.69 & 1984.46 & 1054.43 & 57391.13 & 0.51 & 4587.0 \\
\hline 2011Q1 & 4880.64 & 1836.01 & 642.31 & 58463.50 & 0.80 & 4590.0 \\
\hline 2011Q2 & 4625.25 & 1792.89 & 810.59 & 59404.50 & 0.80 & 4597.0 \\
\hline 2011Q3 & 4855.98 & 1853.22 & 1916.11 & 62067.95 & 0.73 & 4613.0 \\
\hline 2011Q4 & 4319.39 & 1955.63 & 1175.35 & 62446.93 & 0.47 & 4626.0 \\
\hline 2012Q1 & 4912.40 & 2213.33 & 1139.00 & 68426.01 & 0.71 & 4631.0 \\
\hline 2012Q2 & 6955.20 & 2712.08 & 1719.09 & 76212.53 & 0.61 & 4634.0 \\
\hline $2012 Q 3$ & 6514.84 & 2817.52 & 1412.12 & 79949.77 & 0.57 & 4639.0 \\
\hline 2012Q4 & 7065.77 & 1689.64 & 2439.34 & 84103.22 & 0.57 & 4688.0 \\
\hline 2013Q1 & 7414.30 & 3562.28 & 2239.64 & 89678.42 & 0.65 & 4701.0 \\
\hline 2013Q2 & 7457.39 & 2770.19 & 1683.53 & 92166.58 & 0.58 & 4721.00 \\
\hline 2013Q3 & 7737.08 & 2642.04 & 1785.62 & 94468.51 & 0.55 & 4743.00 \\
\hline 2013Q4 & 7477.67 & 3130.31 & 1504.20 & 99413.62 & 0.53 & 4758.00 \\
\hline 2014Q1 & 7908.70 & 3010.79 & 2265.79 & 101886.2 & 0.56 & 4766.00 \\
\hline 2014Q2 & 7796.53 & 2916.26 & 1458.68 & 101935.6 & 0.53 & 4794.00 \\
\hline 2014Q3 & 8189.21 & 3154.71 & 1159.66 & 106546.8 & 0.49 & 4821.00 \\
\hline 2014Q4 & 9435.90 & 3044.88 & 1463.26 & 113256.2 & 0.42 & 4841.00 \\
\hline 2015Q1 & 10242.61 & 3694.46 & 2316.52 & 138479.3 & 0.53 & 4852.00 \\
\hline 2015Q2 & 9654.40 & 3186.90 & 1974.35 & 133763.9 & 0.49 & 4868.00 \\
\hline $2015 Q 3$ & 10385.20 & 3168.70 & 573.63 & 135560.1 & 0.42 & 4892.00 \\
\hline $2015 Q 4$ & 7777.23 & 4036.29 & 950.20 & 134221.4 & 0.49 & 4915.00 \\
\hline 2016Q1 & 7711.25 & 2843.41 & 151.07 & 109371.9 & 0.56 & 4930.00 \\
\hline 2016Q2 & 8213.40 & 3516.25 & 437.34 & 115395.6 & 0.64 & 4953.00 \\
\hline $2016 Q 3$ & 7910.04 & 2931.51 & 611.63 & 113490.3 & 0.54 & 4983.00 \\
\hline 2016Q4 & 7646.28 & 3658.18 & 1111.11 & 114429.7 & 0.60 & 5013.00 \\
\hline 2017Q1 & 7092.79 & 2116.81 & 1181.55 & 102843.7 & 0.61 & 5018.00 \\
\hline
\end{tabular}




\begin{tabular}{lllllll}
\hline 2017Q2 & 8675.41 & 2273.54 & 1084.29 & 113564.7 & 0.58 & 5044.00 \\
\hline 2017Q3 & 9099.48 & 2616.54 & 1162.38 & 116614.0 & 0.58 & 5072.00 \\
\hline 2017Q4 & 9233.96 & 2046.28 & 900.90 & 121065.1 & 0.59 & 5074.00 \\
\hline $\mathbf{2 0 1 8 Q 1}$ & 9142.95 & 2573.25 & 1661.61 & 128875.2 & 0.65 & 5076.00 \\
\hline 2018Q2 & 8404.58 & 2378.66 & 1864.06 & 124925.1 & 0.71 & 5109.00 \\
\hline $\mathbf{2 0 1 8 Q 3}$ & 9024.16 & 2453.18 & 2246.20 & 126657.3 & 0.68 & 5138.00 \\
\hline $\mathbf{2 0 1 8 Q 4}$ & 10477.93 & 2811.11 & 1961.48 & 135343.3 & 0.66 & 5133.00 \\
\hline $\mathbf{2 0 1 9 Q 1}$ & 10739.89 & 3188.03 & 2435.85 & 152419.8 & 0.66 & 5132.00 \\
\hline $\mathbf{2 0 1 9 Q 2}$ & 10676.01 & 3013.96 & 2128.21 & 153284.1 & 0.69 & 5168.00 \\
\hline $\mathbf{2 0 1 9 Q 3}$ & 11605.86 & 3424.33 & 2282.87 & 157521.1 & 0.67 & 5195.00 \\
\hline $\mathbf{2 0 1 9 Q 4}$ & 11208.61 & 3886.82 & 2356.79 & 160515.5 & 0.58 & 5190.00 \\
\hline $\mathbf{2 0 2 0 Q 1}$ & 11979.89 & 4496.80 & 1233.93 & 164985.3 & 0.67 & 5192.00 \\
\hline $\mathbf{2 0 2 0 Q 2}$ & 12597.81 & 5056.99 & 1953.20 & 180254.8 & 0.52 & 5221.00 \\
\hline $\mathbf{2 0 2 0 Q 3}$ & 11886.48 & 4315.59 & 2410.42 & 180470.3 & 0.49 & 5249.00 \\
\hline $\mathbf{2 0 2 0 Q 4}$ & 12055.81 & 3895.19 & 2798.41 & 184130.2 & 0.46 & 5250.31 \\
\hline $\mathbf{2 0 2 1 Q 1}$ & 11348.06 & 4154.80 & 1393.63 & 159468.3 & 0.55 & 5251.00 \\
\hline
\end{tabular}

